УДК 631.4:504.5:622.7

\title{
ЭКОГЕОХИМИЧЕСКИЙ МОНИТОРИНГ ПОЧВЕННОГО ПОКРОВА НА УЧАСТКАХ АЛМАЗОДОБЫЧИ В ЗАПАДНОЙ ЯКУТИИ
}

\author{
Гололобова Анна Григорьевна', \\ nuta0687@mail.ru
}

\author{
Легостаева Яна Борисовна², \\ ylego@mail.ru \\ 1 Научно-исследовательский институт прикладной экологии Севера \\ им. проф. Д.Д. Саввинова Северо-Восточного федерального университета им. М.К. Аммосова, \\ Россия, 677980, г. Якутск, пр. Ленина, 43. \\ 2 Институт геологии алмаза и благородных металлов СО РАН, \\ Россия, 677980, г. Якутск, пр. Ленина, 39.
}

\begin{abstract}
Актуальность исследования обусловлена слабой изученностью воздействия горнодобывающей деятельности на компоненты природной среды в условиях распространения многолетнемерзлых пород.

Цель: геоэкологический мониторинг почвенного покрова на территории разработки коренных месторождений алмазов в Западной Якутии на примере промышленной площадки Нюрбинского горно-обогатительного комбината.

объекты: мерзлотные почвы северо-таежных ландшафтов Западной Якутии.

Методы: потенциометрический, колориметрический, пипеточный, атомно-абсорбционный, статистические методы. Результаты. Представлены данные о состоянии почвенного покрова территории промышленной площадки Нюрбинского горно-обогатительного комбината за десятилетний период - 2007-2018 г2. Геохимический ряд распределения химических элементов в порядке убывания их средних значений для верхнего слоя почв (0-20 см) выглядит следующим образом: $\mathrm{Mn}>\mathrm{Zn}>\mathrm{Ni}>\mathrm{Cu}>\mathrm{Co}>\mathrm{C}>\mathrm{Pb}>\mathrm{As}>\mathrm{Cd}$. Зафриксировано пространственное увеличение контрастности техногенных аномалий, характеризующих активное накопление подвижных форм Mn (в 17 раз), Zn (в 5 раз), Cd (в 2,6 раз), Cr (в 2 раза), Co (в 1,8 раз) и Ni (в 1,6 раза) в поверхностных органогенных горизонтах почв. Накопление $\mathrm{Mn}, \mathrm{Ni}$, Со обусловлено преимущественно природными (типоморфрные кимберлитам элементы) и техногенными (аэрогенное распространение мелкодисперсных частиц в результате буровзрывных работ, ветровая эрозия отвалов) фракторами. Выявлены положительные корреляции между парами $\mathrm{Mn}-\mathrm{Zn}, \mathrm{Mn}-\mathrm{Cd}, \mathrm{Mn}-\mathrm{Pb}, \mathrm{Zn}-\mathrm{Ni}, \mathrm{Zn}-\mathrm{Cd}, \mathrm{Cr}-\mathrm{Cu}(r \geq 0,5)$, а также влияние органического вещества на содержание $\mathrm{Mn}(\mathrm{r}=0,5)$, и значений $\mathrm{pH}$ на содержание $\mathrm{Cr}(r=0,8)$ и $\mathrm{Cu}(r=0,5)$. Построены карты эколого-геохимического состояния почвенного покрова территории промышленной площадки Нюрбинского горно-обогатительного комбината. В настоящий момент более 260 км² $^{2}$ помышленной площадки характеризуется высоко опасной категорией загрязнения почвенного покрова с Zc>128.
\end{abstract}

\section{Ключевые слова:}

Западная Якутия, карьеры по добыче алмазов, кимберлитовые трубки, тяжелые металлы, подвижные формы микроэлементов, мерзлотные почвы, суммарный показатель загрязнения почв.

\section{Введение}

Добыча природных минеральных ресурсов неизбежно приводит к негативному воздействию на состояние окружающей среды. Крайне неблагоприятное влияние на экологическое состояние компонентов экосистемы оказывает открытый способ добычи полезных ископаемых [1]. Вследствие интенсивной разработки открытых месторождений с использованием мощной техники и добывающего оборудования формируются обширные площади с техногенным рельефом, происходит нарушение природного ландшафта, водного режима рек и многие другие проблемы вплоть до локальных и региональных экологических катастроф. В том числе при производстве горных работ происходит загрязнение прилегающих территорий, возникают очаги эрозии, почвенный слой подвергается физическому, механическому и химическому воздействию. За пределы горного отвода распространяются миграционные геохимические потоки, характеризующиеся повышенными концентрациями тяжелых металлов [2-8]. Загрязнение почв тяжелыми металлами, такими как $\mathrm{Pb}, \mathrm{Ni}, \mathrm{Mn}, \mathrm{Cd}, \mathrm{Co}, \mathrm{Cr}, \mathrm{Zn}, \mathrm{Cu}$ и As, довольно опасно $[9,10]$. При этом почвенный по- кров является идеальной депонирующей средой для оценки воздействия горнодобывающих предприятий, что показано во многих российских $[1,4,5,11,12]$ и зарубежных [13-18] работах. Положение осложняется слабой устойчивостью северных экосистем к различным формам антропогенной деятельности [19]. В северных районах почвы, которые считаются «самоочищающимся фильтром» природы, во многом теряют свое обеззараживающее свойство из-за малой мощности профиля, слабого дренажа, ежегодного промерзания, способствующего концентрации в почвенных водах загрязнителей, краткого периода биологической жизни, а также наличия водоупора в виде надмерзлотного горизонта. Эти особенности обусловливают низкую устойчивость мерзлотных почв и ускорение процессов их загрязнения в зонах техногенного давления [1, 20-23]. Следовательно, возникает необходимость проводить оценку загрязнения почв криолитозоны, что является неотъемлемой составной частью комплексных геоэкологических исследований, создающих базу для планирования мероприятий по снижению последствий разработки рудных и россыпных месторождений алмазов в условиях криогенеза. 
Исследования проводились в центральной части Якутской алмазоносной провинции в СреднеМархинском алмазоносном районе. Первые алмазы были выявлены амакинскими геологами в 1950 г. в русловом аллювии р. Марха. И только после 40 лет длительных поисков Ботуобинской комплексной геологоразведочной экспедицией на левобережье $\mathrm{p}$. Марха в междуречье Накын и Хання были обнаружены высокоалмазоносные кимберлитовые трубки Ботуобинская (1994), Нюрбинская (1996), Мархинская (1999) и Майская (2006), сопровождаемые погребенными россыпями алмазов [24-26]. Накынское кимберлитовое поле относится к территориям со сложными поисковыми условиями. Все вмещающие кимберлиты образования и магматические проявления переработаны древней мезозойской корой выветривания, карстовыми процессами и перекрыты мощным (от 40 до 100 м и более) чехлом юрских морских отложений $[27,28]$. В отличие от Мирнинских и Далдыно-Алакитских крупных месторождений, в которых кимберлиты подходят к поверхности, как на «Зарнице», «Мире» или «Удачном». Поэтому, чтобы добраться до рудного тела, нужно произвести вскрышу в размере около 8 млн м ${ }^{3}$ [29]. В результате таких объемных работ на территории промышленной площадки образуются огромные массивы из вскрышных пород - отвалы, являющиеся дополнительным источником выбросов пыли и различных газов.

В результате почти тридцатилетней деятельности создана природно-техногенная система, в которую включены два карьера по добыче кимберлитовой руды «Нюрбинская» и «Ботуобинская», обогатительная фабрика № 15 (с 1999 г.), геологическая фабрика № 17 (небольшая фабрика, построенная в 2007 г.), обогатительная фабрика № 16 (с 2003 г.), вахтовый поселок на 1000 человек, взлетно-посадочные полосы, склад материалов взрывчатых веществ и источники, связанные с процессами добычи и обогащения, - хвостохранилище, отвалы пустых пород, пульпопроводы и др.

Накынское кимберлитовое поле расположено на сочленении Анабаро-Оленекской антиклизы и Вилюйской синеклизы и приурочено к ВилюйскоМархинской кимберлитоконтролирующей тектонической зоне глубинных разломов. Территория представляет собой слабопересеченную местность с перепадом высот не более 50 м. Рельеф территории среднерасчлененное плато. Главной особенностью является расположение в зоне распространения вечной мерзлоты. Резко континентальный климат благодаря значительным колебаниям температур и продолжительности зимнего периода создает благоприятную обстановку для сохранения и развития толщи многолетних пород. В условиях низкой относительной влажности воздуха, высоких летних температур и недостаточного количества атмосферных осадков летнее оттаивание мерзлоты способствует постоянному увлажнению почвы, создавая своеобразную зону развития криогенных процессов. По геоботаническому районированию исследуемая территория входит в среднетаежную и северотаежную подзоны бо- реальной области. Для них характерно развитие древесного яруса, господствующей породой является лиственница Гмелина (Larix gmelinii) и Каяндера (L. cajanderi) [10].

\section{Объекты и методы исследования}

В структуре почвенного покрова территории промышленной площадки Нюрбинского горнообогатительного комбината (НГОКа) распространены следующие подтипы почв: криоземы гомогенные надмерзлотно-глееватые, криоземы гомогенные неоглеенные, криоземы тиксотропные, криоземы глееватые оподзоленные, криоземы гомогенные перегнойно-глеевые, мерзлотные палево-бурые, мерзлотные палевые типичные, мерзлотные дерновокарбонатные, мерзлотные перегнойно-глеевые, мерзлотные аллювиальные дерновые почвы.

Криоземы занимают 84 \% в структуре почвенного покрова территории промышленной площадки НГОКа, являются доминирующими типами почв и характеризуются маломощным почвенным профилем с ярко выраженными процессами криотурбации, приводящими к нарушению цельности генетических горизонтов и перемешиванию почвенного материала по профилю [10].

Полевые исследования были проведены в 2007-2018 гг. с периодичностью в 3-4 года на территории северо-таежных ландшафтов ХанняНакынского междуречья в Западной Якутии в пределах промышленной площадки НГОКа. Для создания информационной базы равномерно по всей площадке заложена сеть наблюдений с шагом опробования $2 \times 2$ км в масштабе 1:100000 км. Пробы почв отбирались по мониторинговым точкам из поверхностного слоя почв на глубину 0-20 см (рис. 1). Параллельно для характеристики почвенного покрова заложены почвенные разрезы в разных биотопах с погоризонтным отбором проб на всю глубину оттайки. Отбор проб, их транспортировку и подготовку к лабораторному анализу осуществляли общепринятыми в почвоведении методами. Всего отобрано и проанализировано 436 проб почвенных образцов.

В образцах почв определяли подвижные формы $\mathrm{Pb}$, $\mathrm{Ni}, \mathrm{Mn}, \mathrm{Cd}, \mathrm{Co}, \mathrm{Cr}, \mathrm{Zn}, \mathrm{Cu}$ и As методом атомноабсорбционной спектрометрии на МГА-915 ГК Люмэкс в экстрагенте $1 \mathrm{H} \mathrm{HNO}_{3}$, который в отличие от $\mathrm{H}_{2} \mathrm{O}$ и $1 \mathrm{H} \mathrm{HCl}$ вытяжек извлекает кислоторастворимые элементы, более прочно связанные с почвой [22, 30-33]. Физико- химические показатели определены потенциометрическим методом (pH), методом колориметрии - содержание органического вещества по И.В. Тюрину, общего азота, гранулометрический состав по Качинскому. Полученные количественные данные были обработаны с использованием программ Microsoft Excel 2013, Statistica 6.0, OriginPro 8.5.1. Построение карт выполнено с помощью программы ArcGIS 9.0.

При санитарно-гигиенической оценке загрязнения почв химическими веществами нормативами являются предельно-допустимые концентрации (ПДК), характеризующие токсичность поллютантов [34]. Для 
оценки интенсивности накопления химических элементов в почве применяли расчетные коэффициенты: коэффициент концентрации $\left(\mathrm{K}_{\mathrm{c}}\right)$, показатель суммарного загрязнения почвенного покрова $\left(\mathrm{Z}_{\mathrm{c}}\right)$, с анализом коэффициентов с $\mathrm{K}_{\mathrm{c}}>1,5$. Градация степени загрязнения почвенного покрова: $\mathrm{Z}_{\mathrm{c}}$ : $<16$ - допустимая; 16-32 - умеренно-опасная; 32-128 - опасная; $\geq 128$ чрезвычайно опасная [35].

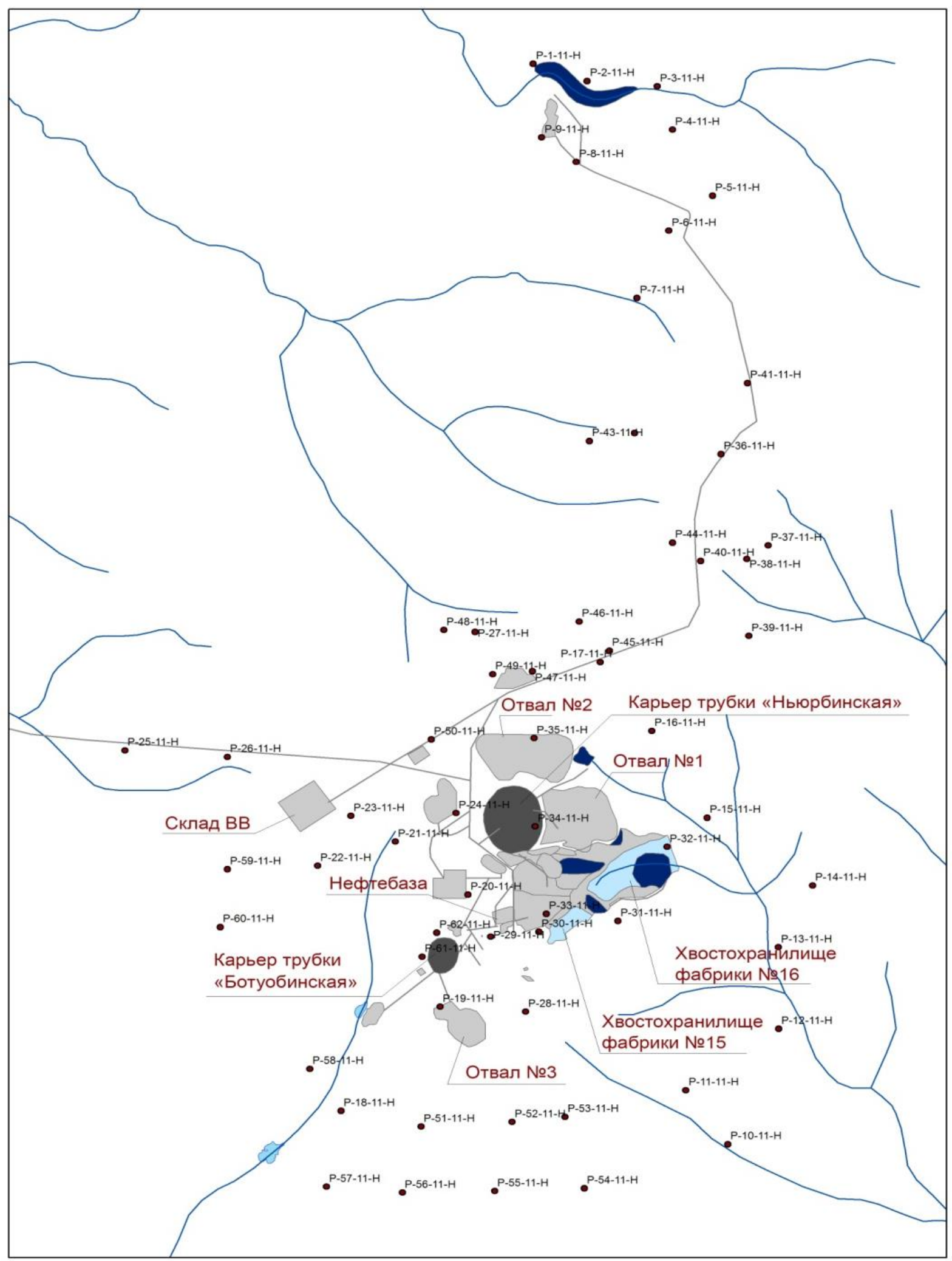

Pис. 1. Карта-схема отбора проб почв на территории промышленной площадки НГОК [10]

Fig. 1. Map-scheme of soil sampling on the territory of industrial site of Nyurbinsky Mining and Processing Plant (NMPP) 


\section{Результаты и их обсуждение}

Физико-химические свойства и геохимическая характеристика почв. За одиннадцатилетний период наблюдения на территории Хання-Накынского междуречья произошли значительные изменения природных ландшафтов, связанные со строительством, эксплуатацией объектов производственного комплекса НГОКа, развивающейся инфраструктурой, введением с 2012 г. карьера трубки «Ботуобинская».

Полученные данные показали, что в настоящий момент почвенный покров территории промзоны НГОКа характеризуется преимущественно кислой реакцией почвенной среды (табл. 1). Самая высокая кислотность характерна для верхних органогенных горизонтов, что связано с наибольшим содержанием органического вещества [36], высокие значения которого обуславливают наличие в почвах средне- и слаборазложившихся органических остатков, что в целом характерно для почв северных областей. Расчет соотношения углерода к азоту $(\mathrm{C} / \mathrm{N}=13)$ свидетельствует о слабом разложении растительных остатков.

Таблица 1. Общие вариационно-статистические характеристики состояния почв территории промышленной площадки НГОКа за период исследований

Table 1. Basic variational-statistical characteristics of soil state in the territory of the industrial site of the NMPP for the period of research

\begin{tabular}{|c|c|c|c|c|}
\hline $\begin{array}{l}\text { Показатель } \\
\text { Index }\end{array}$ & $\mathrm{M} \pm \mathrm{m}$ & Lim & $\begin{array}{c}\text { Доверительный } \\
\text { интервал } \\
\text { при } \mathrm{P}=0,05 \\
\text { Confidence } \\
\text { interval at } \mathrm{P}=0,05\end{array}$ & $\begin{array}{l}\mathrm{V} \\
\%\end{array}$ \\
\hline $\mathrm{pH}_{\text {водн. }} / \mathrm{pH}_{\text {Н2О }}$ & $5,38 \pm 0,12$ & $4,5 \ldots 7,1$ & $5,2 \ldots 5,6$ & 13 \\
\hline Гумус/Gumus, $\%$ & $5,6 \pm 1,1$ & $0,9 \ldots 22,8$ & $2,7 \ldots 8,5$ & 94 \\
\hline $\mathrm{N}_{\text {общ }} / \mathrm{N}_{\text {total }}, \%$ & $13,1 \pm 3,1$ & $2,8 \ldots 40,6$ & $7,0 \ldots 19,2$ & 82 \\
\hline \begin{tabular}{|l|} 
Физическая глина \\
$(<0,01$ мм $)$ \\
Physical clay \\
$(<0,01 \mathrm{~mm}), \%$ \\
\end{tabular} & $22,1 \pm 1,7$ & $3,3 \ldots 31,6$ & $18,7 \ldots 25,5$ & 39 \\
\hline
\end{tabular}

Наиболее высокие содержания отмечены в точках, находящихся непосредственно в зоне влияния промышленных объектов (около карьера трубки «Нюрбинская», отвала № 2, хвостохранилища № 16, вертолетной площадки), что показывает не столько содержание органического вещества, сколько присутствие в почве техногенной составляющей. При этом значительных вариаций содержания гумуса по годам исследований не выявлено. В условиях загрязнения почвы утрачивают естественные черты из-за техногенного подавления процессов почвообразования. Поэтому существуюие методы определения гумуса отражают не столько собственно гумусированность почв, сколько общее содержание углерода в них, в составе которого существенна техногенная составляющая (углеводороды топлива, смазочные масла и др.) [37].

Содержание гумуса в почвенном профиле колеблется в довольно широких пределах: от низкого $(0,6 \%)$ до очень высокого (9,0\%). Отмечаются два пика органического накопления: в верхней части поч- венного профиля, связанного с биогенным накоплением, которое является естественным из-за высокого содержания слабо разложившегося органического вещества, и в нижней части почвенного профиля, являющегося следствием криогенных процессов, связанных с подвижностью гумуса и разрушением вечной мерзлоты, то есть перемешиванием и протеканием через трещины $[10,11,36]$.

Количество физической глины характерно для легкосуглинистого гранулометрического состава, с преобладанием фракций мелкого песка $(0,25 \ldots 0,05$ мм) и ила $(<0,001$ мм). Концентрация многих элементов в составе тонкодисперсных фракций почв как природных, так и техногенных ландшафтов, как правило, в 2-4 раза выше, чем в почве в целом. Это обусловлено главным образом поглотительной способностью глинистых минералов [32, 38].

Специфика элементного состава почвенного покрова связана, с одной стороны, с металлогеническим особенностями территории. С другой стороны, вероятно поступление тяжелых металлов в составе пылевых частиц, образующихся во время буровзрывных работ в карьере, погрузочных работ, транспортировки руды, ветровой эрозии поверхности отвалов, хвостохранилища и бортов карьера [1] и др.

Наиболее активными агентами загрязнения являются подвижные формы микроэлементов, способные переходить из твердых фаз в почвенные растворы и поглощаться растениями $[39,40]$. Среднее содержание подвижных форм микроэлементов в почвах территории промышленной площадки НГОКа составляет (в мг/кг сухого вещества): свинца - 1,64; никеля 7,17 ; марганца - 898,3; кадмия - 0,07; кобальта - 4,87; хрома - 4,30; цинка - 22,9; меди - 6,0; мышьяка - 0,12. Геохимический ряд распределения химических элементов в порядке убывания их средних значений для верхнего слоя почв (0-20 см) выглядит следующим образом: $\mathrm{Mn}>\mathrm{Zn}>\mathrm{Ni}>\mathrm{Cu}>\mathrm{Co}>\mathrm{Cr}>\mathrm{Pb}>\mathrm{As}>\mathrm{Cd}$.

Значения, превышающие фоновые, отмечены для $\mathrm{Mn}$ (до 9 раз), Cd (до 2,3 раз), $\mathrm{Zn}$ (до 2 раз), $\mathrm{Ni}$ и $\mathrm{Co}$ (до 1,5 раз); выше ПДК - Mn (до 14 раз), Zn (до 4 раз), $\mathrm{Cr}$ (до 2 раз), Сd (до 1,6 раз) и Со (до 1,5 раз).

Если сравнивать содержание микроэлементов в почвах промышленной площадки НГОКа за период 2007-2018 гг. (рис. 2), произошло увеличение концентраций $\mathrm{Mn}$ (в 17 раз), Zn (в 5 раз), $\mathrm{Cd}$ (в 2,6 раз), $\mathrm{Cr}$ (в 2 раза), $\mathrm{Co}$ (в 1,8 раз) и $\mathrm{Ni}$ (в 1,6 раза). При этом отмечено снижение количества $\mathrm{Pb}$. Содержание $\mathrm{Cu}$ и As в почвах осталось практически прежним.

На исследуемой территории в качестве реперных точек выбраны участки с разной техногенной нагрузкой и, соответственно, разным уровнем загрязнения почвенного покрова. Геохимические спектры, построенные на основе коэффициента концентрации $($ Кс), позволили выявить степень трансформации элементного состава почв за период наблюдений (табл. 2). Результаты показывают значительное повышение концентраций подвижных форм и расширение микроэлементного ряда. К 2018 г. в составе почвенного покрова промышленной площадки НГОКа прослеживается накопление $\mathrm{Mn}, \mathrm{Zn}$ и $\mathrm{Ni}$. 

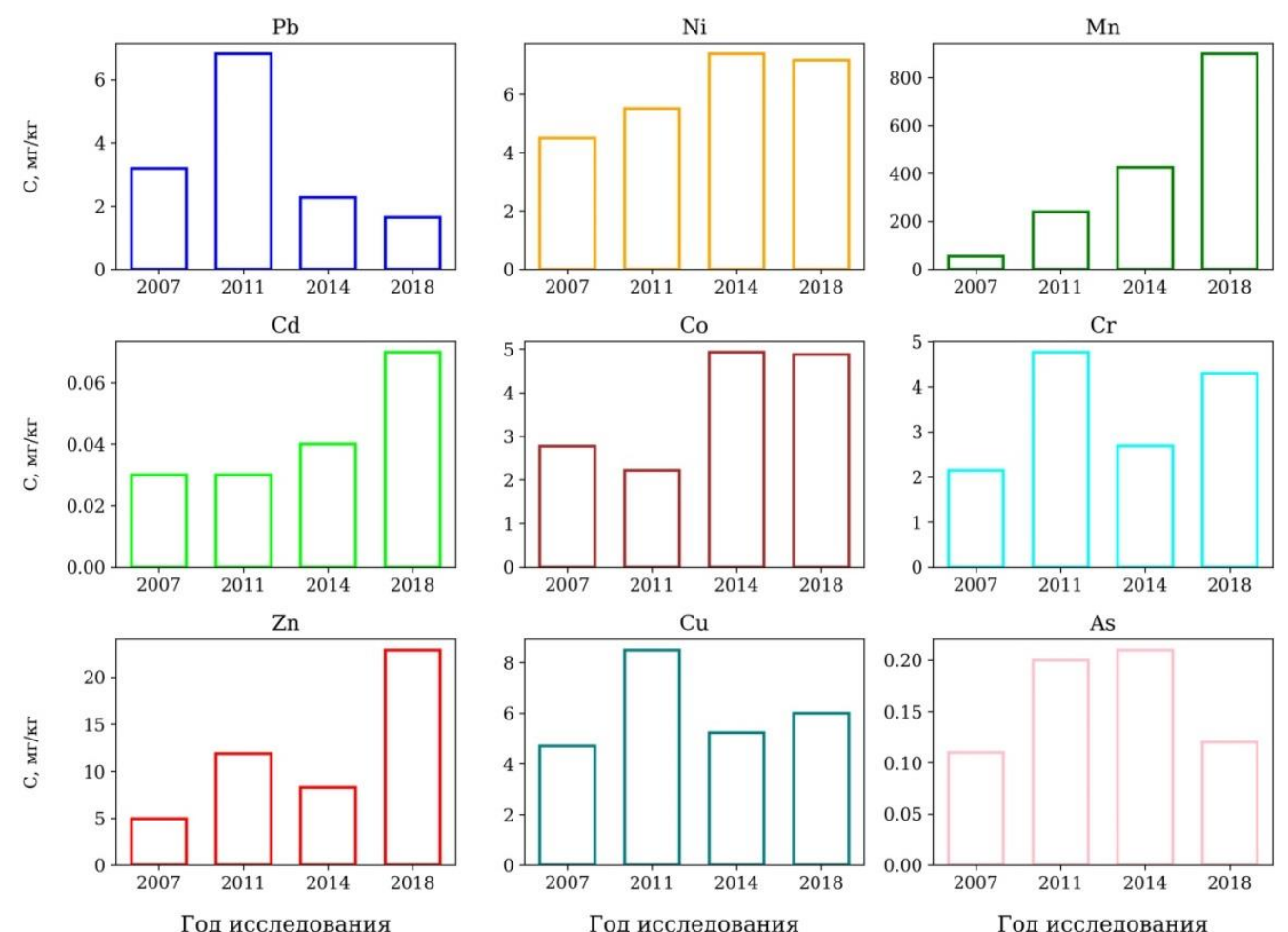

Pис. 2. Динамика содержания средних значений микроэлементов за период 2007-2018 г2.

Fig. 2. Dynamics of the content of the average values of trace elements for 2007-2018

Таблица 2. Характеристика микроэлементного состава почв на ключевых участках промышленной площадки НГОКа по данным исследований 2007-2018 г2.

Table 2. Microelement composition of soils in main sites of the study industrial site of the NMPP according to research for 2007-2018

\begin{tabular}{|c|c|c|c|c|}
\hline \multirow{2}{*}{$\begin{array}{c}\text { № т.н. } \\
\text { №. о.p. }\end{array}$} & \multicolumn{4}{|c|}{ Исследования/Research } \\
\hline & 2007 & 2011 & 2014 & 2018 \\
\hline 11 & $\mathrm{Mn}_{8,7}$ & $\mathrm{Mn}_{24,2} \rightarrow \mathrm{Zn}_{10,7} \rightarrow \mathrm{Cd}_{9,1} \rightarrow \mathrm{Co}_{5,2} \rightarrow \mathrm{Ni}_{2,0} \rightarrow \mathrm{Pb}_{1,7}$ & $\mathrm{Mn}_{20,0} \rightarrow \mathrm{Ni}_{3,5} \rightarrow \mathrm{Co}_{3,0} \rightarrow \mathrm{Cd}_{2,2} \rightarrow \mathrm{Zn}_{1,5}\left(\mathrm{As}_{1,5}\right)$ & $\mathrm{Mn}_{290,4} \rightarrow \mathrm{Zn}_{5,4} \rightarrow \mathrm{Ni}_{3,8} \rightarrow \mathrm{Co}_{3,5} \rightarrow \mathrm{Cd}_{3,0}$ \\
\hline 14 & $\begin{aligned} \mathrm{Mn}_{10,6} & \rightarrow \mathrm{Co}_{5,3} \rightarrow \\
\mathrm{Ni}_{4,8} & \rightarrow \mathrm{Cd}_{2,0}\end{aligned}$ & $\mathrm{Mn}_{44,7} \rightarrow \mathrm{Ni}_{4,1}$ & $\mathrm{Mn}_{19,6} \rightarrow \mathrm{Ni}_{7,0} \rightarrow \mathrm{Co}_{3,7} \rightarrow \mathrm{Zn}_{2,2} \rightarrow \mathrm{Cr}_{2,0} \rightarrow \mathrm{Cd}_{1,5}$ & $\mathrm{Mn}_{141,4} \rightarrow \mathrm{Zn}_{2,5}$ \\
\hline 16 & $\mathrm{Mn}_{6,8} \rightarrow \mathrm{Ni}_{2,3}$ & $\mathrm{Mn}_{20,6} \rightarrow \mathrm{As}_{1,5}$ & $\mathrm{Mn}_{116,2} \rightarrow \mathrm{Ni}_{6,1} \rightarrow \mathrm{Zn}_{3,3} \rightarrow \mathrm{Co}_{3,1} \rightarrow \mathrm{Cd}_{3,0}$ & $\mathrm{Mn}_{186,8} \rightarrow \mathrm{Zn}_{4,7} \rightarrow \mathrm{Ni}_{2,0}$ \\
\hline 19 & $\mathrm{Mn}_{4,3} \rightarrow \mathrm{Ni}_{2,9} \rightarrow \mathrm{Co}_{2,4}$ & $\mathrm{Mn}_{13,3} \rightarrow \mathrm{Ni}_{4,8} \rightarrow \mathrm{Pb}_{2,7}$ & $\begin{aligned} \mathrm{Mn}_{137,2} & \rightarrow \mathrm{Ni}_{26,8} \rightarrow \mathrm{Co}_{12,9} \rightarrow \\
\mathrm{Cd}_{3,4} & \rightarrow \mathrm{As}_{2,3} \rightarrow \mathrm{Zn}_{1,9}\end{aligned}$ & $\mathrm{Mn}_{69,7} \rightarrow \mathrm{Ni}_{4,5} \rightarrow \mathrm{Zn}_{4,1} \rightarrow \mathrm{Cd}_{3,4} \rightarrow \mathrm{Co}_{1,9}$ \\
\hline 24 & $\begin{aligned} \mathrm{Mn}_{8,2} & \rightarrow \mathrm{Ni}_{4,0} \rightarrow \\
\mathrm{Co}_{2,4} & \rightarrow \mathrm{Zn}_{1,6}\end{aligned}$ & $\mathrm{Mn}_{85,0} \rightarrow \mathrm{Ni}_{4,5} \rightarrow \mathrm{Cd}_{4,3} \rightarrow \mathrm{Pb}_{2,8} \rightarrow \mathrm{Zn}_{2,0}$ & $\mathrm{Mn}_{29,6} \rightarrow \mathrm{Ni}_{5,0} \rightarrow \mathrm{As}_{2,3} \rightarrow \mathrm{Co}_{2,1} \rightarrow \mathrm{Zn}_{1,8}$ & $\begin{aligned} \mathrm{Mn}_{447,0} & \rightarrow \mathrm{Ni}_{14,8} \rightarrow \mathrm{Zn}_{8,3} \rightarrow \\
\mathrm{Cd}_{6,0} & \rightarrow \mathrm{Co}_{4,6} \rightarrow \mathrm{As}_{1,7}\end{aligned}$ \\
\hline 28 & $\mathrm{Ni}_{1,8} \rightarrow \mathrm{Mn}_{1,6}$ & $\mathrm{Zn}_{11,6} \rightarrow \mathrm{Cd}_{11,0} \rightarrow \mathrm{Ni}_{4,6} \rightarrow \mathrm{Mn}_{3,6} \rightarrow \mathrm{Pb}_{2,6}$ & $\mathrm{Mn}_{24,2} \rightarrow \mathrm{Ni}_{3,9} \rightarrow \mathrm{As}_{2,0} \rightarrow \mathrm{Cd}_{1,7}$ & $\mathrm{Mn}_{230,3} \rightarrow \mathrm{Cd}_{8,2} \rightarrow \mathrm{Zn}_{5,2} \rightarrow \mathrm{Ni}_{3,2}$ \\
\hline 31 & $\mathrm{Mn}_{3,5} \rightarrow \mathrm{Co}_{1,8} \rightarrow \mathrm{Ni}_{1,7}$ & $\mathrm{Mn}_{6,6} \rightarrow \mathrm{Ni}_{3,9} \rightarrow \mathrm{Co}_{2,5} \rightarrow \mathrm{Cr}_{1,6}$ & $\mathrm{Mn}_{5,0} \rightarrow \mathrm{Ni}_{3,5} \rightarrow \mathrm{As}_{2,1} \rightarrow \mathrm{Co}_{1,8}$ & $\mathrm{Mn}_{127,0} \rightarrow \mathrm{Cr}_{10,0} \rightarrow \mathrm{Ni}_{7,2} \rightarrow \mathrm{Zn}_{6,0} \rightarrow \mathrm{Co}_{4,6} \rightarrow \mathrm{Cd}_{4,1}$ \\
\hline 32 & $\mathrm{Ni}_{2,9}\left(\mathrm{Mn}_{2,9}\right)$ & $\mathrm{Mn}_{40,8} \rightarrow \mathrm{Co}_{6,6} \rightarrow \mathrm{Ni}_{5,5} \rightarrow \mathrm{Pb}_{3,6} \rightarrow \mathrm{Zn}_{2,6}$ & $\mathrm{Mn}_{195,5} \rightarrow \mathrm{Ni}_{12,9} \rightarrow \mathrm{Co}_{3,1} \rightarrow \mathrm{As}_{2,4} \rightarrow \mathrm{Zn}_{2,0}$ & $\mathrm{Mn}_{160,3} \rightarrow \mathrm{Zn}_{4,7} \rightarrow \mathrm{Ni}_{3,0} \rightarrow \mathrm{Cd}_{2,5}$ \\
\hline 33 & $\mathrm{Mn}_{2,0}$ & $\mathrm{Mn}_{17,2} \rightarrow \mathrm{Co}_{8,4} \rightarrow \mathrm{Ni}_{3,9} \rightarrow \mathrm{Pb}_{2,6} \rightarrow \mathrm{Zn}_{1,7}$ & $\mathrm{Mn}_{78,1} \rightarrow \mathrm{Co}_{1,9} \rightarrow \mathrm{Ni}_{1,7}$ & $\mathrm{Mn}_{181,9} \rightarrow \mathrm{Ni}_{12,8} \rightarrow \mathrm{Zn}_{9,4} \rightarrow \mathrm{Co}_{3,5} \rightarrow \mathrm{Cd}_{3,4}$ \\
\hline 34 & $-*$ & $\mathrm{Mn}_{8,0} \rightarrow \mathrm{Pb}_{3,3}\left(\mathrm{Co}_{3,3}\right) \rightarrow \mathrm{Ni}_{2,9} \rightarrow \mathrm{Zn}_{2,3}$ & $\mathrm{Mn}_{7,1} \rightarrow \mathrm{Ni}_{1,6}$ & $\mathrm{Mn}_{27,9} \rightarrow \mathrm{Zn}_{8,0} \rightarrow \mathrm{Ni}_{7,7} \rightarrow \mathrm{Cr}_{6,8} \rightarrow \mathrm{Co}_{4,2} \rightarrow \mathrm{As}_{2,0}$ \\
\hline 35 & $\mathrm{Mn}_{2,6} \rightarrow \mathrm{Ni}_{1,9}$ & $\mathrm{Mn}_{57,3} \rightarrow \mathrm{Ni}_{5,4} \rightarrow \mathrm{Co}_{3,8} \rightarrow \mathrm{Pb}_{3,6} \rightarrow \mathrm{Zn}_{3,2}$ & $\mathrm{Mn}_{85,1} \rightarrow \mathrm{Co}_{3,2} \rightarrow \mathrm{Ni}_{2,5}$ & $\mathrm{Mn}_{669,4} \rightarrow \mathrm{Ni}_{16,11} \rightarrow \mathrm{Zn}_{7,3} \rightarrow \mathrm{Cd}_{4,2} \rightarrow \mathrm{Co}_{3,4}$ \\
\hline 43 & $\mathrm{Mn}_{2,2} \rightarrow \mathrm{Ni}_{1,7}$ & $\begin{aligned} \mathrm{Mn}_{203,8} & \rightarrow \mathrm{Co}_{32,5} \rightarrow \mathrm{Ni}_{8,0} \rightarrow \\
\mathrm{Cd}_{3,7} & \rightarrow \mathrm{Pb}_{3,2} \rightarrow \mathrm{Zn}_{2,6}\end{aligned}$ & $\mathrm{Mn}_{222,0} \rightarrow \mathrm{Co}_{10,7} \rightarrow \mathrm{Ni}_{7,8} \rightarrow \mathrm{Cd}_{1,8}$ & $\mathrm{Mn}_{393,4} \rightarrow \mathrm{Zn}_{12,17} \rightarrow \mathrm{Cd}_{6,2} \rightarrow \mathrm{Ni}_{1,9}$ \\
\hline 50 & $\mathrm{Mn}_{3,3} \rightarrow \mathrm{Co}_{2,7} \rightarrow \mathrm{Ni}_{2,4}$ & $\mathrm{Mn}_{5,2} \rightarrow \mathrm{Pb}_{2,6} \rightarrow \mathrm{Zn}_{1,9} \rightarrow \mathrm{Ni}_{1,7}$ & $\mathrm{Mn}_{131,5} \rightarrow \mathrm{Co}_{7,3} \rightarrow \mathrm{Ni}_{5,8} \rightarrow \mathrm{Zn}_{2,2}$ & $\mathrm{Mn}_{88,4} \rightarrow \mathrm{Ni}_{8,0} \rightarrow \mathrm{Co}_{7,1} \rightarrow \mathrm{Zn}_{4,8} \rightarrow \mathrm{Cd}_{4,7}$ \\
\hline 57 & - & $\mathrm{Mn}_{18,6} \rightarrow \mathrm{Ni}_{2,3} \rightarrow \mathrm{Co}_{2,1} \rightarrow \mathrm{Zn}_{1,8} \rightarrow \mathrm{Pb}_{1,6}$ & $\mathrm{Mn}_{77,8} \rightarrow \mathrm{Ni}_{8,0} \rightarrow \mathrm{Co}_{3,6} \rightarrow \mathrm{As}_{2,5} \rightarrow \mathrm{Zn}_{2,4} \rightarrow \mathrm{Cd}_{1,6}$ & $\mathrm{Mn}_{824,1} \rightarrow \mathrm{Zn}_{5,4} \rightarrow \mathrm{Pb}_{4,4} \rightarrow \mathrm{Ni}_{3,7} \rightarrow \mathrm{Cd}_{3,2}$ \\
\hline 59 & - & $\mathrm{Mn}_{6,7} \rightarrow \mathrm{Cr}_{2,4} \rightarrow \mathrm{Ni}_{2,2} \rightarrow \mathrm{Zn}_{2,1} \rightarrow \mathrm{Pb}_{1,9}$ & $\mathrm{Mn}_{339,8} \rightarrow \mathrm{Ni}_{14,4} \rightarrow \mathrm{Co}_{3,7} \rightarrow \mathrm{Cd}_{2,4} \rightarrow \mathrm{Zn}_{2,3}$ & $\mathrm{Mn}_{430,0} \rightarrow \mathrm{Ni}_{10,6} \rightarrow \mathrm{Cd}_{7,1} \rightarrow \mathrm{Zn}_{5,3} \rightarrow \mathrm{Co}_{1,8}$ \\
\hline 61 & - & - & $\mathrm{Mn}_{22,2} \rightarrow \mathrm{Ni}_{2,7} \rightarrow \mathrm{Co}_{1,6}$ & $\mathrm{Mn}_{119,1} \rightarrow \mathrm{Zn}_{4,9} \rightarrow \mathrm{Ni}_{4,8} \rightarrow \mathrm{Cd}_{3,2} \rightarrow \mathrm{Co}_{2,5}$ \\
\hline
\end{tabular}

Примечание: «т.н.» - точка наблюдения, «-*»- нет превымения фоновых параметров, Кк $\leq 1,5$. Привязка точек наблюдения: 11 - 6 км на юго-восток от хвостохранилища; 14 - 4 км на восток от хвостохранилища; 16 - 2 км на северо-восток от отвала № 1 и хвостохранилища; 19 - около отвала № 3; 24 - развилка дорог; 28 - вертолетная площадка; 31 - 300 м на юг от хвостохранилища; 32 - восточная сторона хвостохранилища; 33 - около фабрики № 15; 34 - около карьера трубки «Нюрбинская»; 35 - около отвала № 2; 43 - 1,5 км на запад от дороги; 50 - дорога в сторону р. Марха; 57 - около буровой техники; 59 - 2 км на юго-запад от склада взрывчатых веществ; 61 - около карьера трубки «Ботуобинская».

Note: "o.p." - observation point, «- *»-no excess of background parameters, $K \kappa \leq 1,5$. Binding of observation points: $11-$ $6 \mathrm{~km}$ to the south-east of the tailing dump; $14-4 \mathrm{~km}$ to the east of the tailing dump; $16-2 \mathrm{~km}$ to the north-east of dump no. 1 and tailings; 19 - near dump no. 3; 24 - crossroads; 28 - helipad; 31 - $300 \mathrm{~m}$ to the south of the tailing dump; 32 eastern side of the tailing dump; 33 - near factory no. 15; 34 - near the quarry «Nyurbinsky»; 35 - near dump no. 2; 43 $1,5 \mathrm{~km}$ to the west of the road; 50 - the road towards the Markha river; 57 - near drilling equipment; 59 - $2 \mathrm{~km}$ to the southwest of the explosives depot; 61 - near the quarry «Botuobinsky». 

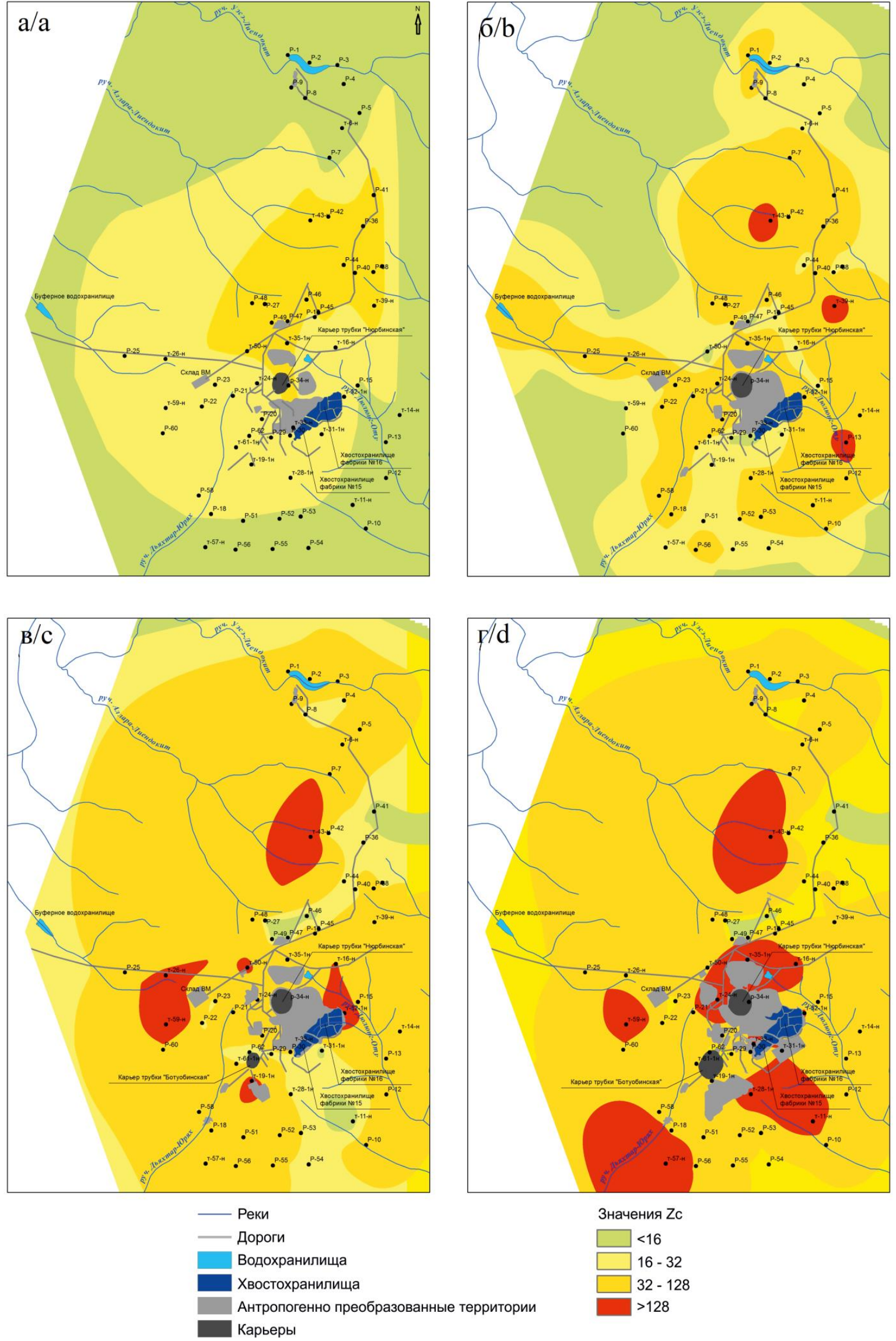

Значения Zc
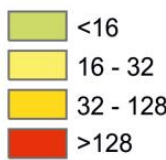

Рис. 3. Карта-схема суммарного загрязнения почвенного покрова территории промышленной площадки НГОКа по годам исследований [44]

Fig. 3. Map-scheme of the total pollution of the soil cover in the territory of industrial site of the NMPP by years of research 
Ранее наблюдалось накопление $\mathrm{Mn}, \mathrm{Ni}, \mathrm{Co}$, которые являются типоморфными кимберлитам и характеризуют как природную геохимическую аномалию, так и техногенную аномалию вторичного поверхностного загрязнения. На данный момент проявляется тенденция накопления Zn, доказывающее наличие техногенной составляющей в почвах промплощадки $[30,41]$.

Корреляционный анализ показал наличие взаимосвязей между концентрацией подвижных форм микроэлементов (все коэффициенты корреляции значимы при уровне значимости $\mathrm{P}<0,05)$. Установлены заметные положительные корреляции между парами $\mathrm{Mn}-\mathrm{Zn}$, $\mathrm{Mn}-\mathrm{Cd}, \mathrm{Mn}-\mathrm{Pb}, \mathrm{Zn}-\mathrm{Ni}, \mathrm{Zn}-\mathrm{Cd}, \mathrm{Cr}-\mathrm{Cu}(\mathrm{r} \geq 0,5)$. Данные связи указывают на синергизм между вышеуказанными группами, т. е. увеличение одного микроэлемента влечет за собой увеличение концентрации другого [40] Так, большое количество пар у марганца и цинка, что объясняет наличие их в первых рядах микроэлементных спектров. Кроме того, выявлено, что количество органического вещества влияет на содержание подвижных форм марганца $(\mathrm{r}=0,54)$. Также довольно тесная зависимость установлена между $\mathrm{pH}$ и концентрацией подвижных форм хрома $(\mathrm{r}=0,76)$ и меди $(\mathrm{r}=0,46)$. При существующих значениях $\mathrm{pH}$ хром и медь являются инертными, т. е. почти полностью выпадают в осадок, чем и можно связать отсутствие этих элементов в микроэлементном спектре [42, 43].

Эколого-геохимическое состояние почвенного покрова территории НГОКа. Почвы исследуемой промышленной площадки характеризуются полиэлементным загрязнением. Использование формулы Саета позволяет оценить степень суммарного загрязнения почв $(\mathrm{Zc})$ несколькими микроэлементами и тяжелыми металлами (рис. 3).

По данным исследований 2007 г. территория промышленной площадки характеризовалась преимущественно умеренно опасной ситуацией по содержанию подвижных форм микроэлементов, что составляло

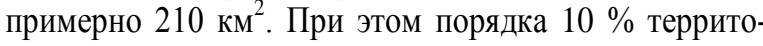
рии относились к высоко опасной категории загряз-

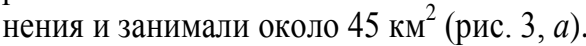

В 2011 г. наблюдалось увеличение условных границ ареалов загрязнения почвенного покрова. Эколого-геохимическая ситуация по-прежнему соответствует в основном категории умеренно опасной $(\sim 305$ км$\left.^{2}\right)$ при наличии участков с высоко опасной степенью загрязнения $\left(\sim 1,44\right.$ км$\left.^{2}\right)$ (рис. $\left.3, \sigma\right)$.

По исследованиям 2014 г. эколого-геохимическая ситуация на территории промышленной площадки НГОКа характеризуется уже преимущественно высоко опасным уровнем загрязнения по показателю $\mathrm{Zc}$ [41] (рис. 3, в). Произошло увеличение ареала высоко опасного загрязнения на $120 \mathrm{kм}^{2}$. Помимо этого, зафиксированы три площадные и две точечные высококонтрастные аномалии с чрезвычайно опасным уровнем загрязнения почвенного покрова, общая площадь которых в условных границах составляет порядка $18,2 \mathrm{KM}^{2}$.

Таким образом, наблюдается пространственное увеличение контрастности выявленных техногенных аномалий, характеризующих активное накопление подвижных форм микроэлементов в поверхностных органогенных горизонтах почв. Тренд увеличения имеет северо-западное и юго-восточное направление.

Исследования 2018 г. позволили локализовать и подтвердить увеличение площади загрязнения почвенного покрова на территории промышленной площадки НГОКа (табл. 3). Эколого-геохимическая ситуация ухудшилась с увеличением пощади и контрастности загрязнения почв (рис. 3, 2). Необходимо подчеркнуть, что наряду с общим увеличением площади загрязнения повысились абсолютные значения коэффициентов концентрации и, соответственно, суммарного показателя загрязнения.

Таблица 3. Площчадь и уровень загрязнения почвенного покрова на территории промышленной площзади НГОКа

Table 3. Area and pollution level of soil cover in the territory of NMPP industrial site

\begin{tabular}{|c|c|c|c|c|c|}
\hline \multirow{2}{*}{$\begin{array}{c}\text { Категория } \\
\text { загрязне- } \\
\text { ния } \\
\text { Pollution } \\
\text { category } \\
\end{array}$} & \multirow{2}{*}{$\begin{array}{c}\text { Уровень суммарного } \\
\text { показателя } \\
\text { загрязнения Zc [35] } \\
\text { Index of total } \\
\text { pollution Zc } \\
\end{array}$} & \multicolumn{4}{|c|}{$\begin{array}{c}\text { Площадь по годам } \\
\text { исследований, км } \\
\text { Area by years of research, } \\
\text { km² }^{2}\end{array}$} \\
\hline & & 2007 & 2011 & 2014 & 2018 \\
\hline $\begin{array}{l}\text { Допусти- } \\
\text { мая } \\
\text { Permissible }\end{array}$ & $<16$ & 222,5 & 171,5 & 70,0 & 61,0 \\
\hline $\begin{array}{l}\text { Умеренно } \\
\text { опасная } \\
\text { Moderately } \\
\text { dangerous } \\
\end{array}$ & $16-32$ & 210,0 & 305,0 & 267,0 & 104,9 \\
\hline $\begin{array}{l}\text { Высоко } \\
\text { опасная } \\
\text { Highly } \\
\text { dangerous } \\
\end{array}$ & $32-128$ & 45,0 & 1,44 & 122,0 & 260,9 \\
\hline $\begin{array}{l}\text { Чрезвы- } \\
\text { чайно } \\
\text { опасная } \\
\text { Extremely } \\
\text { dangerous }\end{array}$ & $>128$ & - & - & 18,2 & 51,6 \\
\hline
\end{tabular}

\section{Заключение}

Результаты проведенных исследований выявили высокий уровень загрязнения почвенного покрова тяжелыми металлами на территории промышленной площадки НГОКа, где производят взрывные работы на карьерах, буровые работы, а также в районе отвалов вскрышных пород, хвостохранилища, склада взрывчатых веществ и вертолетной площадки.

Исследуемая территория расположена в зоне природной геохимической аномалии, сформированной в почвах в результате внедрения кимберлитов, высокие концентрации $\mathrm{Ni}, \mathrm{Cr}, \mathrm{Co}, \mathrm{Cu}$ и $\mathrm{Mn}$ в почвах отражают геохимическую специфику территории Накынского кимберлитового поля. Анализ коэффициентов концентрации показал, что в почвенном покрове происходит также интенсивная аккумуляция марганца, цинка и никеля на участках, охватывающих основные объекты загрязнения.

Составлен геохимический ряд распределения химических элементов в порядке убывания их средних значений: $\mathrm{Mn}>\mathrm{Zn}>\mathrm{Ni}>\mathrm{Cu}>\mathrm{Co}>\mathrm{Cr}>\mathrm{Pb}>\mathrm{As}>\mathrm{Cd}$. Выявлено синергическое взаимодействие марганца с цинком, кадмием, свинцом, а также цинка с никелем и 
кадмием, вызванное под действием стресса из-за избыточных концентраций тяжелых металлов. В почвах промышленной площадки отмечены аномально высокие содержания подвижных кислоторастворимых форм марганца, превышения нормативов по общесанитарному показателю вредности подвижных форм $\mathrm{Ni}$ в 1,8 раз, $\mathrm{Mn}$ в 8,5 раз и $\mathrm{Cu}$ в 1,7 раз.

В формировании степени загрязнения почвенного покрова определённую роль играет ветровой перенос загрязняющих веществ, образующихся в результате добычи руды открытым способом, а также при пылении бортов карьеров, отвалов, хвостохранилища [1]. Выявленные ареалы с высокоопасным загрязнением почвенного покрова пространственно приурочены к карьерам трубок, отвалам пустых пород, территориям возле хвостохранилищ и россыпным проявлениям.

\section{СПИСОК ЛИТЕРАТУРЫ}

1. Белошейкина А.В., Таловская А.В., Язиков Е.Г. Экологогеохимическая оценка состояния почвенного покрова территории Сорского горного-обогатительного комбината (Республика Хакасия) // Известия Томского политехнического университета. Инжиниринг георесурсов. - 2020. - Т. 331. - № 1. - С. 44-53.

2. Евлампиева Е.П., Панин М.С. Накопление цинка, меди и свинца лишайником в районе угледобывающего месторождения «Каражыра» // Вестник томского государственного университета. - 2008. - № 314. - С. 196-200.

3. Сорокина О.А., Киселев В.И. Загрязнение почв в зоне освоения Джалиндинского россыпного и рудного месторождений золота в Приамурье // Экология и промышленность России. 2005. - № 7. - С. 24-28.

4. Басова И.А., Иоина М.А., Глухова Е.Н. Геоэкологическое состояние почвенного покрова в горнопромышленных регионах // Известия Тульского государственного университета. - 2010. - № 1. - C. 16-20.

5. Басова И.А., Иватанова Н.П., Копылов А.Б. Оценка экологического состояния почв в регионах с развитой горной промышленностью // Известия Тульского государственного университета. - 2012. - № 1-2. - С. 14-16.

6. Исмаилов Б.Т. Технология управления природнотехническими системами при открытой разработке нагорных месторождений доломитов // Горный информационноаналитический бюллетень (научно-технический журнал). 2011. - № 9. - C. 68-74.

7. Heavy metal pollution caused by small-scale metal ore mining activities: a case study from a polymetallic mine in South China Z. Sun, X. Xie, P. Wang, Yu. Hu, H. Cheng // Science of the Total Environment. - 2018. - V. 639. - P. 217-227.

8. Environmental impacts of unmanaged solid waste at a former base metal mining and ore processing site (Kirki, Greece) / A. Liakopoulos, B. Lemiere, K. Michael, C. Crouzet, V. Laperche, I. Romaidis, I. Drougas, A. Lassin // Waste Management \& Research. - 2010. - № 28. - P. 996-1009.

9. Environmental monitoring of soils of post-industrial mining areas / V. Pohrebennyk, P. Koszelnik, O. Mitryasova, E. Dzhumelia, M. Zdeb // Journal of Ecological Engineering. - 2019. - V. 20. Iss. 9. - P. 53-61.

10. Дягилева А.Г. Устойчивость к химическому загрязнению криоземов Западной Якутии: дис. ...канд. биол. наук. - Улан-Удэ, 2015. - 178 c.

11. Gololobova A.G., Legostaeva Ya.B. Heavy metals in cryozems of Western Yakutia // Water Resources. Forest, Marine and Ocean Ecosystems conference proceedings. - Bulgaria, 2019. - V. 19. B. 3.2. - P. 239-246.

12. Легостаева Я.Б., Ксенофонтова М.И., Дягилева А.Г. Экологогеохимический мониторинг почвенного покрова в зоне воздействия Нюрбинского ГОКа // Горный журнал. - 2014. № 4. - C. 117-120.

13. Bradl H.B. Heavy metals in the environment. Interface. In book: Science and Technology. - London: Elsevier Ltd., 2005. - 269 p.
В 2018 г. по сравнению с 2007 г. содержание поллютантов в верхнем слое почвы значительно увеличилось. Состояние почвенного покрова промышленной площадки Нюрбинского горно-обогатительного комбината оценивается как высокоопасное (Zc>128), что связано с увеличением промышленного производства и разработкой второго карьера кимберлитовой трубки «Ботуобинская».

Статья подготовлена в рамках выполнения проектов Государственного задания Минобразования PФ FSRG2020-0018 «Изучение особенностей функционирования арктических и субарктических экосистем Якутии в условиях усиления техногенного воздействия и глобального изменения климата» $u$ FUEM-2019-0003 «Экологогеохимическое изучение техногенных массивов на территории Якутской алмазоносной провиниии».

14. Demkova L., Jezny T., Bobulska L. Assessment of soil heavy metal pollution in a former mining area - before and after the end of mining activities // Soil \& Water Research. - 2017. - V. 12 (4). - P. 229-236.

15. Different exposure profile of heavy metal and health risk between residents near a $\mathrm{Pb}-\mathrm{Zn}$ mine and $\mathrm{Mn}$ mine in Huayuan county, South China / Y. Du, L. Chen, P. Ding, B. Chen, Y. Duan // Chemosphere. - 2019. - V. 216. - P. 352-364. DOI: 10.1016/j.chemosphere.2018.10.14

16. Evaluation of heavy metal contamination of surface soils in Zarshouran gold district, Northwestern Iran / F. Ghazban, A. Parizanganeh, A. Zamani, S. Baniardalan // International Journal of environmental research. - 2018. - V. 12 (6). - P. 843-860.

17. Evaluation of soil contamination indices in a mining area of Jiangxi, China / J. Wu, Y. Teng, S. Lu, Y. Wang, X. Jiao // PLoS ONE. - 2014. - V. 9. - Iss. 11. - P. e112917. DOI: 10.1371/journal.pone.0112917

18. Zhang J., Yao D. Geochemical characteristics and source analysis of soil heavy metals in Luling coal mine, northern Anhui Province // Institute of Physics Conference Series: Earth and Environmental Science. - 2018. - V. 189 (3). - P. 032058.

19. Вольперт Я.Л., Мартынова Г.А. Основные направления минимизации воздействия алмазодобывающей промышленности Якутии на окружающую среду // Горный журнал. - 2011. № 1. - С. $100-102$.

20. Макаров В.Н. Эколого-геохимическая оценка техногенного воздействия на окружающую среду Якутии // География и природные ресурсы. - 2010. - № 1. - С. 45-48.

21. Тентюков М.П. Особенности распределения химических элементов в мерзлых почвах // Криосфера Земли. - 2013. T. 17. - № 3. - C. 100-107.

22. Gololobova A.G., Legostaeva Ya.B. The stability of frozen soils in conditions of development of mining industry // Water Resources. Forest, Marine and Ocean Ecosystems conference proceedings. Bulgaria, 2017. - V. 17. - Iss. 32. - P. 655-662. DOI: $10.5593 /$ sgem $2017 / 32 / \mathrm{S} 13.085$

23. Legostaeva Ya.B. Migration of microelements in the profile of cryozem in north-west Yakutia // Life Science Journal. - 2014. V. 11. - Iss. 7s. - P. 406-409.

24. Килижеков О.К., Толстов А.В. Закономерности образования и размещения промышленных россыпей алмазов в Накынском кимберлитовом поле (Якутская алмазоносная провинция) // Наука и образование. - 2017. - № 1. - С. 12-20.

25. Килижеков О.К., Толстов А.В. Новые возможности прироста запасов алмазов в Средне-Мархинском районе Якутии // Месторождения алмазов: процессы формирования, закономерности локализации, методы прогнозирования и поисков. Труды Рабочего совещания. - Новосибирск: Федеральное государственное бюджетное учреждение науки Институт геологии и минералогии им. В.С. Соболева Сибирского Отделения Российской академии наук, 2016. - С. 54-60.

26. Новое тело высокоалмазоносных кимберлитов в Накынском поле Якутской алмазоносной провинции / А.В. Толстов, В.А. Минин, В.Б. Василенко, Л.Г. Кузнецова, А.Н. Разумов // Геология и геофизика - 2009. - Т. 50. - № 3. - С. 227-240. 
27. Оценка перспектив и локальное прогнозирование кимберлитов с помощью гис-технологий на закрытых территориях Накынского кимберлитового поля, Западная Якутия / П.А. Игнатов, К.В. Новиков, А.М. Шмонов, Р.В. Еремеев, Л.В. Лисковая, О.Е.Ковальчук, А.В. Толстов // Руды и металлы. - 2012. № 4. - С. 54-60.

28. Коробков И.Г., Евстратов А.А., Мильштейн Е.Д. Базитовые вулканоструктуры алмазоносных районов восточного борта Тунгусской синеклизы. - Томск: STT, 2013. - 270 с.

29. Редакция. Крупнейшая отрасль крупнейшего субъекта федерации в крупнейшем экономическом районе // География. 2008. - № 11. URL: https://geo.1sept.ru/article.php?ID=200801117 (дата обращения 10.11.2020).

30. Дягилева А.Г. Экологическая оценка геохимического состояния техногенно-загрязненных почв // Международный журнал прикладных и фундаментальных исследований. - 2013. № 8. - С. 53-55.

31. М 03-07-2009. Методика выполнения измерение массовой доли элементов ( $\mathrm{As}, \mathrm{Cd}, \mathrm{Co}, \mathrm{Cr}, \mathrm{Cu}, \mathrm{Hg}, \mathrm{Mn}, \mathrm{Ni}, \mathrm{Pb}, \mathrm{V}, \mathrm{Zn}$ ) в пробах почв, грунтов и донных отложений ПНД Ф 16.1:2:2.2.63-09. M., 2009. -40 c.

32. Мотузова Г.В. Устойчивость почв к химическому воздействию. - М.: Изд-во МГУ, 2000. - 57 с.

33. Сысо А.И. Закономерности распределения химических элементов в почвообразующих породах и почвах Западной Сибири. - Новосибирск: Изд-во СО РАН, 2007. - 275 с.

34. Методические рекомендации по геохимической оценке загрязнения территорий городов химическими элементами / под ред. Б.А. Ревич, Ю.Е. Сает, Р.С. Смирнова, Е.П. Сорокина. М.: ИМГРЭ, 1982. - $112 \mathrm{c}$

35. Геохимия окружающей среды / Ю.Е. Сает, Б.А. Ревич, Е.П. Янин и др. - М.: Недра, 1990. - 335 с.

36. Дягилева А.Г. Гумус как показатель устойчивости почв к химическому загрязнению // Гуминовые вещества в биосфере: VI Всероссийская научная конференция с международным участием. - Сыктывкар: Коми НЦ УрО РАН, 2014. - С. 160-163.
37. Прохорова Н.В. Эколого-геохимическая роль автотранспорта в условиях городской среды // Вестник Самарского государственного университета: Естественнонаучная серия. - 2005. № 5 (39). - С. 188-199.

38. Дягилева А.Г. Устойчивость к химическому загрязнению криоземов Западной Якутии: автореф. дис ...канд. биол. наук. Улан-Удэ, 2015. - 22 с.

39. Михальчук Н.В. Подвижные формы тяжелых металлов и микроэлементов в почвах карбонатного ряда юго-запада Беларуси // Известия Национальной академии наук Беларуси. Серия химических наук. - 2017. - № 3. - С. 90-97.

40. Свечникова А.А. Закономерности аккумуляции валовых и подвижных форм микроэлементов в почвах Астраханской области // Естественные науки. - 2013. - № 1 (42). - С. 23-28.

41. Дягилева А.Г., Легостаева Я.Б. Влияние техногенеза на экологическое состояние мерзлотных почв (на примере Нюрбинского ГОКа) // Вестник Северо-Восточного федерального университета им. М.К. Аммосова. - 2013. - Т. 10. - № 2. С. 79-84.

42. Влияние техногенного воздействия на содержание валовых и подвижных форм тяжелых металлов в почвах / О.Я. Соколова, А.В. Стряпков, С.В. Антимонов, С.Ю. Соловых // Вестник Оренбургского государственного университета. - 2006. T. 2. - № 2. - C. 35-42.

43. Kabata-Pendias A. Trace elements in soils and plants. 4th ed. Roca Raton: CRS Press, 2011. - 548 p.

44. Легостаева Я.Б. Эколого-геохимическая характеристика наземных экосистем // Мониторинг состояния наземных и водных экосистем в зоне влияния Нюрбинского горнообогатительного комбината: отчет о научноисследовательской работе Научно-исследовательского института прикладной экологии Севера Северо-Восточного федерального университета. Отв. исп. Я.Л. Вольперт - Якутск, 2018. $-235 \mathrm{c}$

Поступила 18.11.2020 2.

\section{Информация об авторах}

Гололобова А.Г., кандидат биологических наук, старший научный сотрудник лаборатории мерзлотных почв Научно-исследовательского института прикладной экологии Севера им. проф. Д.Д. Саввинова СевероВосточного федерального университета им. М.К. Аммосова.

Легостаева Я.Б., кандидат биологических наук, ведущий научный сотрудник лаборатории металлогении Института геологии алмаза и благородных металлов СО РАН. 
UDC 631.4:504.5:622.7

\title{
ECOGEOCHEMICAL MONITORING OF SOIL COVER ON DIAMOND MINING SITE IN WESTERN YAKUTIA
}

\author{
Anna G. Gololobova 1 , \\ nuta0687@mail.ru \\ Yana B. Legostaeva², \\ ylego@mail.ru \\ 1 M.K. Ammosov North-Eastern Federal University, \\ 43, Lenin avenue, Yakutsk, 677980, Russia. \\ 2 Diamond and Precious Metal Geology Institute, Siberian Branch of the Russian Academy of Sciences, \\ 39, Lenin avenue, Yakutsk, 677980, Russia.
}

The relevance of the study is caused by poor knowledge of the mining activities impact on the environment components in the conditions of permafrost distribution.

The main aim: geoecological monitoring of soil cover in the area of development of primary diamond deposits in Western Yakutia on the example of the industrial site of the Nyurbinsky mining and processing plant.

Objects: frozen soils of the north-taiga landscapes of Western Yakutia.

Methods: potentiometric, colorimetric, pipette, atomic absorption, statistical methods

Results. The paper introduces the data on the state of the soil cover of the industrial site of the Nyurbinsky mining and processing plant for a ten-year period - 2007-2018. The geochemical series of distribution of chemical elements in decreasing order of their average values for the upper 0-20 cm soil layer is as follows: $\mathrm{Mn}>\mathrm{Zn}>\mathrm{Ni}>\mathrm{Cu}>\mathrm{Co}>\mathrm{Cr}>\mathrm{Pb}>\mathrm{As}>\mathrm{Cd}$. A spatial increase in the contrast of technogenic anomalies was recorded, characterizing the active accumulation of mobile forms Mn (17 times), Zn (5 times), Cd (2,6 times), Cr (2 times), Co (1,8 times) and $\mathrm{Ni}(1,6$ times) in the surface organogenic horizons of soils. The accumulation of $\mathrm{Mn}, \mathrm{Ni}$, Co is mainly caused by natural (typomorphic to kimberlite elements) and technogenic (aerogenic distribution of fine particles as a result of drilling and blasting operations, wind erosion of dumps) factors. The authors have identified positive correlations between the pairs $\mathrm{Mn}-\mathrm{Zn}, \mathrm{Mn}-\mathrm{Cd}, \mathrm{Mn}-\mathrm{Pb}, \mathrm{Zn}-\mathrm{Ni}, \mathrm{Zn}-\mathrm{Cd}, \mathrm{Cr}-\mathrm{Cu}(\mathrm{r} \geq 0,5)$, as well as the effect of organic matter on the content of $\mathrm{Mn}(r=0,5)$, and $\mathrm{pH}$ values for the content of $\mathrm{Cr}(r=0,8)$ and $\mathrm{Cu}(r=0,5)$. Maps of the ecological and geochemical conditions of the soil cover of the industrial site of the Nyurbinsky mining and processing plant were constructed. At present, more than $260 \mathrm{~km}^{2}$ of the industrial site is characterized by a highly hazardous category of soil pollution with Zc $>128$.

\section{Key words:}

Western Yakutia, quarries for diamond mining, kimberlite pipes, heavy metals, mobile forms of trace elements, frozen soils, total soil pollution.

The paper was prepared within the projects of the State Task of the Ministry of Education of the RF FSRG-2020-0018 «Studying the features of Yakutia arctic and subarctic ecosystems functioning under conditions of increasing man-made impact and global climate change» and FUEM-2019-0003 «Ecological and geochemical study of man-made arrays in the territory of Yakutia diamond-bearing province».

\section{REFERENCES}

1. Belosheykina A.V., Talovskaya A.V., Yazikov E.G. Ecological and geochemical assessment of Sorsk mining and processing plant soil cover (republic of Khakassia). Bulletin of the Tomsk Polytechnic University. Geo Assets Engineering, 2020, vol. 331, no. 1, pp. 44-53. In Rus.

2. Evlampieva E.P., Panin M.S. Nakoplenie tsinka, medi i svintsa lishaynikom $\mathrm{v}$ rayone ugledobyvayushchego mestorozhdeniya «Karazhyra» [Accumulation of zinc, copper and lead by lichen in the area of the Karazhyra coal deposit]. Vestnik tomskogo gosudarstvennogo universiteta, 2008, no. 314, pp. 196-200.

3. Sorokina O.A., Kiselev V.I. Chemical pollution of soils in the area of development of Dzhalindinsky alluvial and ore deposits of gold (Amur region). Ecology and Industry of Russia, 2005, no. 7, pp. 24-28. In Rus.

4. Basova I.A., Ioina M.A., Glukhova E.N. Geoekologicheskoe sostoyanie pochvennogo pokrova v gornopromyshlennykh regionakh [Geoecological condition of soil cover in mining regions]. Izvestiya Tulskogo gosudarstvennogo universiteta: nauki o zemle, 2010, no. 1, pp. 16-20.

5. Basova I.A., Ivatanova N.P., Kopylov A.B. Otsenka ekologicheskogo sostoyaniya pochv v regionakh s razvitoy gornoy promyshlennostyu [Assessment of the ecological state of soils in regions with developed mining]. Izvestiya Tulskogo gosudarstvennogo universiteta: estestvennye nauki, 2012, no. 1-2, pp. 14-16.
6. Ismailov B.T. Tekhnologiya upravleniya prirodno-tekhnicheskimi sistemami pri otkrytoy razrabotke nagornykh mestorozhdeniy dolomitov [Technology for managing natural-technical systems in open pit mining of dolomite deposits]. Gorny informatsionnoanaliticheskiy byulleten (nauchno-tekhnicheskiy zhurnal), 2011, no. 9 , pp. $68-74$

7. Sun Z., Xie X., Wang P., Hu Yu., Cheng H. Heavy metal pollution caused by small-scale metal ore mining activities: a case study from a polymetallic mine in South China. Science of the Total Environment, 2018, vol. 639, pp. 217-227.

8. Liakopoulos A., Lemiere B., Michael K., Crouzet C., Laperche V., Romaidis I., Drougas I., Lassin A. Environmental impacts of unmanaged solid waste at a former base metal mining and ore processing site (Kirki, Greece). Waste Management \& Research, 2010, vol. 28, pp. 996-1009.

9. Pohrebennyk V., Koszelnik P., Mitryasova O., Dzhumelia E., Zdeb M. Environmental Monitoring of Soils of Post-Industrial Mining Areas. Journal of Ecological Engineering, 2019, vol. 20, Iss. 9, pp. 53-61.

10. Dyagileva A.G. Ustoychivost k khimicheskomu zagryazneniyu kriozemov Zapadnoy Yakutii. Dis. Kand. nauk [Resistance to chemical pollution of cryozems of Western Yakutia. Cand. Diss.]. UlanUde, 2015. $178 \mathrm{p}$.

11. Gololobova A.G., Legostaeva Ya.B. Heavy metals in cryozems of Western Yakutia. Water Resources. Forest, Marine and Ocean 
Ecosystems conference proceedings, 2019, vol. 19, book 3.2, pp. 239-246.

12. Legostayeva Ya.B., Ksenofontova M.I., Dyagileva A.G. Ecological-geochemical monitoring of the soil cover in the influence zone of the Nyurba mining and processing integrated works. Mining Journal, 2014, no. 4, pp. 117-120. In Rus.

13. Bradl H.B. Heavy metals in the environment. Interface. Science and Technology. London, Elsevier Ltd., 2005. 269 p.

14. Demkova L., Jezny T., Bobulska L. Assessment of soil heavy metal pollution in a former mining area - before and after the end of mining activities. Soil \& Water Research, 2017, vol. 12 (4), pp. 229-236.

15. Du Y., Chen L., Ding P., Chen B., Duan Y. Different exposure profile of heavy metal and health risk between residents near a $\mathrm{Pb}$ Zn mine and Mn mine in Huayuan county, South China. Chemosphere, 2019, vol. 216, pp. 352-364. DOI: 10.1016/ j.chemosphere.2018. 10.14

16. Ghazban F., Parizanganeh A., Zamani A., Baniardalan S. Evaluation of heavy metal contamination of surface soils in Zarshouran gold district, Northwestern Iran. International Journal of environmental research, 2018, vol. 12 (6), pp. 843-860

17. Wu J., Teng Y., Lu S., Wang Y., Jiao X. Evaluation of soil contamination indices in a mining area of Jiangxi, China. PLOS ONE, 2014, vol. 9, Iss. 11, pp. e112917. DOI: 10.1371/journal. pone. 0112917

18. Zhang J., Yao D. Geochemical characteristics and source analysis of soil heavy metals in Luling coal mine, northern Anhui Province. Institute of Physics Conference Series: Earth and Environmental Science, 2018, vol. 189 (3), pp. 032058.

19. Volpert Ya.L., Martynova G.A. The main directions of minimizing influence of diamong-bearing industry of Yakutia on environment. Mining Journal, 2011, no. 1, pp. 100-102. In Rus.

20. Makarov V.N. Ecological and geochemical assessment of technogenic impact on the environment of Yakutia. Geography and Nat ural Resources, 2010, no. 1, pp. 45-48. In Rus.

21. Tentyukov M.P. Features of distribution of chemical elements in frozen soils. Earth`s Cryosphere, 2013, vol. 17, no. 3, pp. 100-107. In Rus.

22. Gololobova A.G., Legostaeva Ya.B. The stability of frozen soils in conditions of development of mining industry. Water Resources. Forest, Marine and Ocean Ecosystems conference proceedings, 2017, vol. 17, Iss. 32, pp. 655-662. DOI: 10.5593/sgem2017/32 /S13.085

23. Legostaeva Ya.B. Migration of microelements in the profile of cryozem in north-west Yakutia. Life Science Journal, 2014 vol. 11, Iss. 7s, pp. 406-409.

24. Kilizhekov O.K., Tolstov A.V. Laws of formation and placing of industrial placer diamonds in the Nakyn kimberlite field (Yakut diamondiferous province). Science and education, 2017, no. 1, pp. 12-20. In Rus.

25. Kilizhekov O.K., Tolstov A.V. Novye vozmozhnosti prirosta zapasov almazov v Sredne-Markhinskom rayone Yakutii [New opportunities for increasing diamond reserves in the middle Markha district of Yakutia]. Mestorozhdeniya almazov: protsessy formirovaniya, zakonomernosti lokalizatsii, metody prognozirovaniya i poiskov. Trudy rabochego soveshchaniya [Diamond deposits: formation processes, localization patterns, forecasting and prospecting methods. Meeting Proc.]. Novosibirsk, 2016. pp. 54-60.

26. Tolstov A.V., Minin V.A., Vasilenko V.B., Kuznetsova L.G., Razumov A.N. A new body of highly diamondiferous kimberlites in the Nakyn field of the Yakutian kimberlite province. Russian Geology and Geophysics, 2009, vol. 50, no. 3, pp. 227-240. In Rus.

27. Ignatov P.A., Novikov K.V., Shmonov A.M., Eremeev R.V., Liskovaya L.V., Kovalchuk O.E., Tolstov A.V. Estimation of the prospects and local prediction of kimberlites using gis-technology in closed areas of Nakyn kimberlite field, Western Yakutia. Ores and Metals, 2012, no. 4, pp. 54-60. In Rus.

28. Korobkov I.G., Evstratov A.A., Milshtein E.D. Bazitovye vulkanostruktury almazonosnykh rayonov vostochnogo borta Tungusskoy sineklizy [Basic volcanostructures of diamondiferous regions of the eastern side of the Tunguska syneclise]. Tomsk, STT Publ., 2013. 270 p.

29. Krupneyshaya otrasl krupneyshego subekta federatsii v krupneyshem ekonomicheskom rayone [The largest industry of the largest federal subject in the largest economic region]. Geografiya,
2008, no. 11. Available at: https://geo.1sept.ru/article.php?ID $=200801117$ (accessed 10 November 2020).

30. Dyagileva A.G. Environmental assessment of geochemical state technogenic-contaminated soils. International journal of applied and fundamental research, 2013 , no. 8, pp. 53-55.

31. M 03-07-2009. Metodika vypolneniya izmerenie massovoy doli elementov (As, $\mathrm{Cd}, \mathrm{Co}, \mathrm{Cr}, \mathrm{Cu}, \mathrm{Hg}, \mathrm{Mn}, \mathrm{Ni}, \mathrm{Pb}, \mathrm{V}, \mathrm{Zn}$ ) v probakh pochv, 147 gruntov $i$ donnykh otlozheniy PND F 16.1:2:2.2.63-09 [Procedure for measuring the mass fraction of elements (As, Cd, $\mathrm{Co}, \mathrm{Cr}, \mathrm{Cu}, \mathrm{Hg}, \mathrm{Mn}, \mathrm{Ni}, \mathrm{Pb}, \mathrm{V}, \mathrm{Zn}$ ) in samples of soils, 147 soils and bottom sediments PND F 16.1: 2: 2.2.63-09.]. Moscow, 2009. $40 \mathrm{p}$.

32. Motuzova G.V. Ustoychivost pochv $k$ khimicheskomu vozdeystviyu [Chemical resistance of soils]. Moscow, MGU Publ., 2000. 57 p.

33. Syso A.I. Zakonomernosti raspredeleniya khimicheskikh elementov v pochvoobrazuyushchikh porodakh i pochvakh Zapadnoy Sibiri [Patterns of distribution of chemical elements in parent rocks and soils of Western Siberia]. Novosibirsk, SO RAN Publ., 2007. $275 \mathrm{p}$

34. Metodicheskie rekomendatsii po geokhimicheskoy otsenke zagryazneniya territoriy gorodov khimicheskimi elementami [Guidelines for the geochemical assessment of pollution of urban areas with chemical elements]. Eds. B.A. Revich, Yu.E. Saet, R.S. Smirnova, E.P. Sorokina. Moscow, IMGRE Publ., 1982. 112 p.

35. Saet Yu.E., Revich B.A., Yanin E.P. Geokhimiya okruzhayushchey sredy [Geochemistry of the environment]. Moscow, Nedra Publ., 1990. $335 \mathrm{p}$.

36. Dyagileva A.G. Gumus kak pokazatel ustoychivosti pochv k khimicheskomu zagryazneniyu [Humus as an indicator of soil resistance to chemical pollution]. VI Vserossiyskaya nauchnaya konferentsiya s mezhdunarodnym uchastiem. Guminovye veshchestva $v$ biosfere [VI All-Russian scientific conference with international participation. Humic substances in the biosphere]. Syktyvkar, Komi Scientific Center of the Ural Branch of the Russian Academy of Sciences Publ., 2014. pp. 160-163.

37. Prokhorova N.V. Ecological and geochemical role of vehicles in urban environments. Vestnik of Samara University. Natural Science Series, 2005, no. 5 (39). pp. 188-199. In Rus.

38. Dyagileva A.G. Ustoychivost k khimicheskomu zagryazneniyu kriozemov Zapadnoy Yakutii. Avtoreferat Dis. Kand. nauk [Resistance to chemical pollution of cryozems of Western Yakutia. Cand. Diss. Abstract]. Ulan-Ude, 2015. 22 p.

39. Mikhalchuk N.V. Mobile forms of heavy metals and trace elements in carbonate range soils of the southwest part of Belarus. Proceedings of the National Academy of Sciences of Belarus, Chemical Series, 2017, no. 3, pp. 90-97. In Rus.

40. Svechnikova A.A. Content and forms of microelements found in the soil of Astrakhan region. Problems of Regional Ecology and Nature Management, 2013, no. 1 (42), pp. 23-28. In Rus.

41. Dyagileva A.G., Legostaeva Ya.B. Influence of technogenesis on ecological condition of cryogenic soils (on the example of Nyurbinsky mining and processing combine). Vestnik of NorthEastern Federal University. Series Earth Sciences, 2013, vol. 10, no. 2, pp. 79-84. In Rus.

42. Sokolova O.Ya., Stryapkov A.V., Antimonov S.V., Solovykh S.Yu. Influence of man-caused impact on content of gross and active forms of heavy metals in soil. Vestnik of the Orenburg State University, 2006, vol. 2, no. 2. pp. 35-42. In Rus.

43. Kabata-Pendias A. Trace elements in soils and plants. $4^{\text {th }}$ ed. Boca Raton, FL, CRC Press, 2011. 548 p.

44. Legostaeva Ya.B. Ekologo-geokhimicheskaya kharakteristika nazemnykh ekosistem [Ecological and geochemical characteristics of terrestrial ecosystems]. Monitoring sostoyaniya nazemnykh $i$ vodnykh ekosistem $v$ zone vliyaniya NGOKa: otchet o nauchnoissledovatelskoy rabote Nauchno-issledovatelskogo instituta prikladnoy ekologii Severa Severo-Vostochnogo federalnogo universiteta [Monitoring the state of terrestrial and aquatic ecosystems in the zone of influence of the Nyurbinsky mining and processing plant: research report of Scientific Research Institute of Applied Ecology of the North, North- Eastern Federal University]. Responsible executor: Ya.L. Vol'pert. Yakutsk, 2018. 235 p.

Received: 18 November 2020 


\section{Iformation about the authors}

Anna G. Gololobova, Cand. Sc., senior researcher, M.K. Ammosov North- Eastern Federal University.

Yana B. Legostaeva, Cand. Sc., leading researcher, Diamond and Precious Metal Geology Institute, Siberian Branch of the Russian Academy of Sciences. 